\title{
FOREIGN LANGUAGE TRAINING AS A COMPONENT OF PROFESSIONAL TRAINING OF UKRAINIAN OFFICERS
}

\section{ІНШОМОВНА ПІДГОТОВКА ЯК СКЛАДНИК ПРОФЕСІЙНОЇ ПІДГОТОВКИ УКРАЇНСЬКИХ ОФІЦЕРІВ}

The article reveals the peculiarities of foreign language training as a component of professional training of officers of the Armed Forces of Ukraine. It is noted that the result of professional foreign language training is professional foreign language competence. The author defines the professional competence of an officer as an integral characteristic of a specialist who is able to carry out professional activities on the basis of acquired competencies. Professional competence presupposes the presence of motivational-evaluation, cognitive, communicative, as well as control-evaluation components that promote the development of creative potential, professional self-development and self-improvement of a serviceman. It also analyzes that competence is a set of human competencies realized in different areas of activity. It is determined that professional competence is characterized by the degree of mastery of key, basic competencies, and foreign language competence as a system of competencies which includes general cultural, intercultural, social and cultural, professional, communicative and foreign language competencies. Language and speech, discourse, strategic, intercultural, pragmatic, special, socio-informational as well as personal competencies are distinguished among the competencies of foreign language competence. The author also singles out four interconnected blocks of pedagogical conditions for the formation of professional foreign language competence of servicemen: organizational - a set of actions and interactions that involve determining the criteria and levels of professional competence, selection of technical equipment; methodical - a set of forms, methods, teaching aids, which are aimed at mastering the content of subjects and the formation of professional competencies of servicemen; technological - improving the training process of officers, increasing its effectiveness, intensity; use of interactive forms and methods; psychological - diagnostics of the development of servicemen at each training session, creation of a system of stimulation and positive motivation, atmosphere of cooperation and cocreation between all participants of the educational process.

Key words: professional training of Ukrainian officers, foreign language training, professional competence, professional foreign language competence, system of competencies, components of professional foreign language competence, STANAG 6001.

Candidate of Pedagogical Sciences, Associate Professor at the Department of Foreign Languages Zhytomyr S.P. Korolov Military Institute підготовки офріцерів Збройних Сил України. Зазначено, що результатом профресійної іншомовної підготовки є професійна іншомовна компетентність. Автором визначено профресійну компетентність офріцера як інтегральну характеристику спеціаліста, який здатний здійснювати професійну діяльність на основі набутих компетенцій. Професійна компетентність передбачає наявність мотиваційно-оцінного, когнітивного, комунікативного, а також контрольно-оцінного компонентів, що сприяють розвитку творчого потенціалу, професійному саморозвитку та самовдосконаленню військовослужбовця. Проаналізовано, що компетентність - це сукупність компетенцій людини, які проявляються в різних сорерах діяльності. Визначено, що професіійна компетентність характеризується ступенем володіння ключовими, базовими компетенціями, а іншомовна компетентність як система компетенцій включає загальнокультурну, міжкультурну, соціокультурну, фрахову, комунікативну та іншомовні компетенції. Серед компетенцій іншомовної компетентності також виділено: мовну та мовленнєву, дискурсну, стратегічну, міжкультурну, прагматичну, спеціальну, соціально-інфрормаційну та особистісну.

Автором виділено чотири взаємопов'язаних між собою блоки педагогічних умов фрормування професійної іншомовної компетентності військовослужбовців: організаційні - сукупність дій та взаємодій, що передбачають визначення критеріїв та рівнів професійної компетентності, підбір технічного оснащення занять; методичні сукупність фрорм, методів, засобів навчання, які спрямовані на засвоєння змісту предметів та формування профеесійних компетенцій військовослужбовців; технологічні - вдосконалення діяльності навчання офріцерів, підвищення їі результативності, інтенсивності; використання інтерактивних фрорм та методів навчання, які забезпечують досягнення високого результату; психологічні - діагностика розвитку військовослужбовиів на кожному навчальному занятті, створення системи стимулювання і позитивної мотивації, атмосфери співпраці та співтворчості між усіма учасниками освітнього процесу.

Ключові слова: професійна підготовка українських офріцерів, іншомовна підготовка, профресійна компетентність, профресійна іншомовна компетентність, система компетенцій, компоненти професійної іншомовної компетентності, СТАНАГ 6001.
Formulation of the problem in general. The deepening of Ukraine's strategic partnership with NATO and the modern reform of its armed forces determine the growing role of professional foreign language training in the general system of officer's training and increasing the requirements.
One of the ways to implement Ukraine-NATO relations is cooperation within the framework of the Partnership for Peace Program, which provides Ukraine's participation in joint activities of separate units of the Armed Forces of Ukraine (hereinafter the Armed Forces), that must act together and cooperate with 
units and forces of other countries and apply NATO regulations.

The main tasks and requirements for the professional training of servicemen of the Armed Forces of Ukraine in accordance with modern challenges are reflected in the Laws of Ukraine "On Higher Education", the Military Doctrine of Ukraine. The system of language training of personnel of the Armed Forces of Ukraine is regulated by the Concept of language training of personnel of the Armed Forces of Ukraine, which defines the principles of foreign language training of officers, the main tasks for its improvement, stages and ways of implementation [6].

Analysis of recent research and publications. Results of researches of ukrainian and foreign scientists on methodology of professional education (A. Aleksyuk, A. Vitchenko, O. Vnukova, A. Galimov, B. Gershunsky, S. Goncharenko, A. Zelnitsky, V. Zagvyazinsky, I. Zyazyun, A. Kalensky, V. Kremen, S. Maksymenko, O. Novikov, etc.), competence approach in education (O. Dubasenyuk, O. Zastelo, I. Zymnya, O. Ovcharuk, V. Krykun, N. Mykytenko, V. Luhovy, E. Lodatko, O. Plakhotnik, J. Raven, V. Svistun, V. Ternopilska, A. Khutorsky, etc.), modern learning technologies (A. Vitchenko, A. Verbytsky, I. Dychkivska, A. Panfilova, E. Polat, S. Sysoeva, M. Choshanov, etc.), problems of military and professional education (G. Artyushyn, I. Bloshchynsky, L. Zaika, Y. Zakharchyshyna, A. Zelnytsky, A. Kalensky, S. Lenkov, L. Maslak, M. Neschadym, O. Prokhorov, etc.), psychological aspects of training military specialists (V. Aleshchenko, V. Barannik, O. Kit), S. Kubitsky, S. Maksimenko, V. Osyodlo, R. Okhremenko, S. Peter, G. Rzhevsky, E. Potapchuk, O. Safin, V. Stasiuk, E. Starokon, O. Khmilyar, etc.) have became a conceptual, theoretical and methodological basis for scientific research.

The purpose of this article is to reveal the problem of professional foreign language training of Ukrainian officers as a part of professional training of servicemen, to suggest ways to solve it and to determine the conditions for successful learning of a foreign language in higher military educational institution.

Presenting the main material. The need for effective communication has become an urgent problem due to peacekeeping operations, where language misunderstandings can cause errors, which in the worst case can lead to casualties [3, p. 1].

In addition, many Ukrainian servicemen do not know the rules of conduct of a peacekeeper, the peculiarities of the culture of the people where peacekeeping operations take place, and so on.

Problems can arise not only during communication, solving certain problems with the local population, but also in interpersonal interaction.

The specifics of the professional activities of servicemen require them to be ready for effective interpersonal interaction with subordinates, colleagues, as well as with citizens in everyday life and extreme situations. This makes special demands on the formation of foreign language competence of the officer, i.e, not only to improve the content and methods of his training, but also to develop his spiritual culture $[3$, p. 5].

Therefore, the next problem that arises in the preparation of the peacekeeping contingent - the language culture of the individual, which depends on the language consciousness, which is determined by speech abilities and demonstrated through communicative speech skills $[9$, p. 3].

An officer who studies a foreign language and culture is becoming multilingual and develops his own interculture, which provides the opportunity to act using specific linguistic means.

Professionally oriented foreign language training of officers takes into account the military orientation and is focused on the tasks associated with their professional activities. The result of a foreign language training of servicemen is the practical mastery of a foreign language at the level necessary for carrying out professional duties. The command of the foreign language is demonstrated in the formation of a professional foreign language competence.

The methodological basis for teaching the discipline is modern teaching technology based on communicative and competence-based approaches. The main methodological principles that are implemented professionally in the process of foreign language training of officers are the following:

- the principle of speech orientation of training;

- the principle of integrated teaching of four types of speech activities

(reading, speaking, listening, writing);

- the principle of individualization;

- the principle of reliance on the native language;

- interactivity [1, p. 148].

It is worth noting the educational and ideological function and significant potential of the discipline "Foreign language" to solve complex educational problems.

Foreign language is both a goal and a means teaching. In general, foreign language education in military educational establishments has a huge potential, because it organically combines four aspects: cognitive (knowledge of foreign culture and language as its component), developmental (development of various abilities and speech mechanisms), educational (education of moral qualities of the person) and instructional (mastering of abilities to speak, read, write in a foreign language) [12, p. 467].

It's obvious that the result of professional foreign language training is the professional foreign language competence.

Researchers of military pedagogy believe that the professional competence of a serviceman presupposes professional military knowledge, skills, 
abilities, professionalism in the field of psychology and pedagogy, perfect methods of military activities $[1 ; 2 ; 5 ; 7 ; 10]$.

The professional competence of the officer is based on the professional profile of the serviceman, in which the following substructures can be distinguished:

1) professional orientation: motives, value orientations, professional position, socio-professional status;

2) professional competence: communicative, special, extreme, professional and self-competence;

3) professionally important qualities: intellectual and managerial abilities, emotional and volitional stability;

4) professionally significant psycho physiological features: peculiarities of psychological functions; sensory-perceptual, psychomotor and physical properties and qualities [5, p. 4].

The skills are among the components of any professional competence. At the heart of the officer's activity, researchers distinguish eight types of different skills. They include design (determine ways to implement any activity); adaptive (apply your plan in certain conditions of the military situation); organizational (organize any kind of work); motivational (motivate subordinates to military activities); communicative (communicate during educational and military activities and outside it at the intercultural level) as well as cognitive (conduct research activities) skills [5, p. 102]

Thus, the professional competence of the officer can be represented as an integrated characteristic of the specialist who is able to perform professional activities on the basis of acquired competencies.

Professional competence presupposes the presence of motivational and evaluative, cognitive, communicative as well as control-evaluation components that promote the development of creative potential, professional self-development and self-improvement of a serviceman [2, p. 74].

Thus, we can conclude that competence is a set of human competencies, which are manifested in different areas of activity.

If professional competence is determined by the degree of mastery of key, basic competencies, then foreign language competence as a system of competencies includes general cultural, intercultural, sociocultural, professional, communicative and foreign language competencies [5, p. 95].

The works of $M$. Kenel and $M$. Svein deserve attention, where they distinguish four componentscompetency in foreign language communicative competence:

Grammar competency - the level of mastering the grammar code by the communicant, including vocabulary, spelling and pronunciation rules, word formation and sentence construction;

Sociolinguistic competency - the ability to appropriately use and understand grammatical forms in different sociolinguistic contexts to perform certain communicative functions (description, message, belief, request for information, etc.);

Discourse or expression competency - the ability to combine individual sentences into a coherent message, discourse, using various syntactic and semantic means;

Strategic competency - the ability to use verbal and nonverbal means at the risk of disruption of communication in case of "insufficient level of competency of the communicator or due to side effects" [10, p. 15]. Modern researchers emphasize that this model of foreign language communicative competence has had a significant impact on further research on the problem.

However, L. Bachmann offers a completely different from the previous model of foreign language communicative competence, which includes:

- Language competence;

- Strategic competence;

- Psychophysiological mechanisms

M. Palasyuk and O. Chorna claim that person's foreign language competence includes a set of competencies of foreign language in integration with other knowledge, skills, abilities that provide the ability of the individual to solve problems that appear in professional and socio-cultural environments. According to the scholar's conclusions, this competence includes the following components: linguistic competency (knowledge of language tools; knowledge of language material, the rules of its use in practice); thematic competency (mastery of extralinguistic means); pragmatic competency (ability of the user logically associates the sentence with the goal formulation of coherent fragments of speech); social and cultural competency (knowledge of social and cultural context); compensatory competency (ability to reach mutual understanding with other people); educational competency (the ability to use reference books to ensure language acquisition for the purpose of communication); communicative competence (ability to communicate and interact with the interlocutor) $[7 ; 8]$.

Thus foreign language professional and communicative competence can be considered by us as a set of three components: motivational, cognitive and emotional-volitional. Motivational component includes characteristics such as interest in learning a foreign language and awareness of its importance for future careers, the desire to improve their own language level and acquire new skills in various types of speech activities, interest in creative activities in vocational classes of foreign language teaching, etc. The cognitive component unites foreign language communicative competency in the field of professional activity as subject competency in mastering a professionally-oriented foreign language and general (universal) competencies that represent professionally important qualities of a modern qualified officer [4, p. 47]. 
We have identified that foreign language professional competence includes of a set of the following basic (key) competencies:

1. Linguistic competency, in which we distinguish language and speech competency. By language competence we mean knowledge of lexical units and grammar rules that turn lexical units into meaningful ones utterances, as well as the ability to apply these rules in the process of expression and perception of judgments in oral and written forms. By speech competence we mean knowledge of the rules of language behavior, choice of language forms and means and their use depending on the purposes, situations of communication and social status of participants in the process of socio-cultural and professional communication.

2. Discourse competency, which allows establishing the contextual meaning of coherent text and logically building sentences in the process of communication.

3. Strategic competency, by which we mean ability to use adequate communication situations, verbal and nonverbal communication strategies for the effective intercultural communication.

4. Intercultural competency is the ability to interact with the native speakers taking into account national values, norms and ideas, to create positive mood for communicators in communication, to choose communicatively expedient ways of verbal and nonverbal behavior, using knowledge about the science and culture of representatives of different cultures.

5. Social (pragmatic) competency as the ability of the language personality choose an adequate way of communication depending on the conditions and goals of specific communication situation, build sentences according to the communicative goals of communication participants.

6. Linguistic and professional (subject, special) competency under which we understand the ability to perceive and produce texts in the field of special subject activity, the ability to operate in a foreign language and special vocabulary, cliché language for special purposes, analyze, make a presentation on professionally oriented issues.

7. Social and informational competency that characterizes the ability to express a critical attitude to a wide range of information in the process of intercultural foreign language interaction in professional and domestic spheres of activity and determines the level of ownership of information technology.

8. Personal (personal, individual) competence as an ability that allows to reveal in the process of communication in the context of dialogue of cultures individual values and aspirations of the individual as a social individual, as a willingness to increasing the level of competences for intercultural purposes of professional communication, continuous self-education and self-improvement, and also the need to update personal potential [9, p. 15].
It is necessary to emphasize that the formation of a foreign language professional competence, is necessary to ensure the practical orientation of foreign language training, namely, the foreign language course must be closely related to a number of special disciplines studied by students from profile courses.

For example, the process of learning a foreign language by servicemen must include: 1) the structure of the language being studied, phonetics, grammar, vocabulary); 2) the features of STANAG; 3) STANAG 6001 requirements; 4) structure of messages, reports, presentations [6].

We also distinguish four interconnected blocks of pedagogical conditions: organizational - provide the definition of criteria and levels of professional competence, selection of technical equipment for classes; methodical are defined as a set of forms, methods, teaching aids that are aimed at mastering the content of subjects and the formation of professional competencies of servicemen; technological - aimed at improving learning activities, increasing its effectiveness, intensity; include interactive forms and teaching methods; psychological -include diagnosis of the development of servicemen in each training session, the creation of the system of stimulation and positive motivation, an atmosphere of cooperation between all participants in the educational process[5, p. 96].

Conclusion. In this paper we have come to conclusion that the professional competence of the officer can be represented as an integrated characteristic of the specialist who is able to perform professional activities on the basis of acquired competencies.

Professional competence presupposes the presence of motivational and evaluative, cognitive, communicative as well as control-evaluation components that promote the development of creative potential, professional self-development and self-improvement of a serviceman.

Organizational, methodical, technological and psychological conditions are necessary to form foreign language competence of Ukrainian Army officers.

\section{REFERENCES:}

1. Зязюн І.А. Неперервна професійна освіта: проблеми, пошуки, перспективи: монографрія. Київ, 2000. $636 \mathrm{c}$.

2. Канова Л.П. Інтегрований підхід у формуванні готовності курсантів вищого військового навчального закладу до спілкування на міжкультурному рівні. Актуальні проблеми професійно-педагогічної освіти та стратегії розвитку : зб. наук. праць. Житомир: ЖДУ, 2006. С. 73-75.

3. Капітанець С.В. Педагогічні умови стилю професійного спілкування у майбутніх офріцерівприкордонників:авторефр.дис.наздобуттянаук.ступеня канд. пед. наук: 13.00.04 / Академія прикордонних військ України ім. Богдана Хмельницького. Хмельницький. 2001. С. 73-74. 
4. Левченко Т.І. Розвиток освіти та особистості в різних педагогічних системах. Вінниця, 2002. 512 с.

5. Маслак Л.П. Педагогічні умови формування культурологічної компетентності майбутніх офріцерів радіоінженерних спеціальностей: дис. ... канд. пед. наук : 13.00.04 / Житомир. держ. пед. ун-т. Житомир, 2010. 323 c.

6. Матеріали НАTO : веб-сайт. URL: https://www. Nato.int/docu/review/2005/issue (дата звернення: 12.10.2021).

7. Паласюк М. Формування іншомовної комунікативної компетентності у студентів вищих технічних закладів освіти. Людинознавчі студіі: зб. наук. пр. Дрогобицького держ. пед. ун-ту імені Івана Франка. Серія: Педагогіка. Дрогобич: Вид. відділ ДДПУ імені Івана Франка, 2014. Випуск 29. Ч. 1. С. 144-154.

8. Чорна О.О. Особливості та практика формування іншомовної комунікативної компетентності студентів технічних спеціальностей. Викладання мов у вищих навчальних закладах освіти на сучасному етапі. Міжпредметні зв'язки. Наукові дослідження. Досвід. Пошуки. 2013. Вип. 22. C. 230-237.

9. Шумовецька С.П. Формування мовної культури особистості у військовому вузі: авторефр. дис. на здобуття наук. ступеня канд. пед. наук: 13.00.04 / Академія прикордонних військ України ім. Богдана Хмельницького. Хмельницький, 1999. 20 с.

10. Canal M. From Communicative Competence to Communicative Language Pedagogy. Richards J. and Schmidt R. (eds.). Language and Communication. London: Longman, 1983. P. 2-27.

11. Michael $\mathrm{H}$. Long and Catherine J. Doughty. The Handbook of Language Teaching. Edited by 2009 Blackwell Publishing Ltd. 790p.

12. Pet'ko L. Preparing higher school graduates in foreshortening of leader competencies for 2020. Topical questions of contemporary science: Collection of scientific articles. Aspekt Publishing of Budget Printing Center, Taunton, MA 02780, United States of America, 2017. P. 467-472. 